\title{
Degrees of Emotion: Judicial Responses to Victim Impact Statements
}

\author{
Mary Lay Schuster
}

\section{Amy Propen}

\begin{abstract}
Emotional standards and hierarchies in the courtroom may affect judicial reactions to victim impact statements. Based on judicial conversations and courtroom observations in two judicial districts in Minnesota, we suggest that judges contrast emotion with reason in order to maintain control of their courtrooms; when faced with emotional expressions in victim impact statements, judges appreciate expressions of compassion and tolerate expressions of grief but are uncomfortable with expressions of anger. These judicial responses to emotional expression, however, must be contextualized; for example, the judges we spoke with often articulated different reactions to impact statements given by victims of sexual assault, those who are strangers to the perpetrator, and impact statements given by victims of domestic violence, those who are in a relationship with the perpetrator.
\end{abstract}

The legislated right to give a victim impact statement comes out of the victim rights movement, which generated efforts such as rape crisis centers; victim/witness advocacy programs; hotlines and shelters for battered women; mandatory arrest policies in domestic violence cases; restitution programs; stalking statutes; community notification laws; the online national sex offender registry; and amber alerts. Minnesota Statute 611A.038, which addresses victim impact statements, is typical in its language and scope: 
(a) A victim has the right to submit an impact statement to the court at the time of sentencing or disposition hearing. The impact statement may be presented to the court orally or in writing, at the victim's option. If the victim requests, the prosecutor must orally present the statement to the court. Statements may include the following, subject to reasonable limitations as to time and length:

(1) a summary of the harm or trauma suffered by the victim as a result of the crime;

(2) a summary of the economic loss or damage suffered by the victim as a result of the crime; and

(3) a victim's reaction to the proposed sentence or disposition.

Under Minnesota Statute 611A.037, the victim also may submit a statement to be included in the presentencing investigation report as to "what disposition the victim deems appropriate for the defendant," which includes "the reasons given, if any, by the victim in support of the victim's opinion."1

Scholarly and legal debates about victim impact statements raise questions about whether impact statements present constitutional challenges, bring victims closure and healing, or affect sentencing decisions. Recent Supreme Court cases about capital cases in which the jury makes the sentencing decision focus on the constitutional challenges. In Booth v. Maryland (1987), for example, the Supreme Court ruled victim impact evidence inadmissible in capital sentencing decisions because its admission introduced a "constitutionally unacceptable risk that the jury might impose the death penalty in an arbitrary and capricious manner" by focusing on the victim's character and effects on survivors, a decision upheld in South Carolina v. Gathers (1989). ${ }^{2}$ In 1991, however, the Supreme Court reconsidered the argument that impact evidence violated a defendant's Eighth Amendment rights and ruled in Payne v. Tennessee (1991) that the victim's character and the harm caused to the victim may be considered in sentencing decisions. ${ }^{3}$ Although the court settled the constitutional challenges raised by impact statements, legal scholars continue to worry about the effects of bringing such emotional expressions into the courtroom. On the one hand, John Stickels, for example, concludes that Payne shows that impact evidence explains "human cost and is admissible during the punishment phase of the trial because it is relevant to show the harm caused by the defendant's crime" (247). ${ }^{4}$ On the other hand, scholars such as Susan Bandes state, "victim impact statements are narratives that should be suppressed because they evoke emotions inappropriate in the context of criminal sentencing. Specifically, victim impact statements appeal to hatred, the desire for undifferentiated vengeance, and

1. Minnesota Statutes 611A.037-038 (Copyright (C) 2007 by the Office of Revisor of Statutes, State of Minnesota) can be found at http://www.leg.state.mn.us/leg/statutes.asp.

2. Booth v. Maryland 482 U.S. 496 (1987); South Carolina v. Gathers 490 U.S. 805, 810 (1989).

3. Payne v. Tennessee 501 U.S. 808, 811 (1991).

4. John W. Stickels, "Victim Impact Evidence: The Victims' Right That Influences Criminal Trials," Texas Tech Law Review 32 (2000-2001), pp. 231-47. See, also, Valerie Finn-DeLuca, "Victim Participation at Sentencing," Criminal Law Bulletin (1994), pp. 403-28; and Edith Greene and Heather Koehring, "Victim Impact Evidence in Capital Cases: Does the Victim's Character Matter?" Journal of Applied Social Psychology 28 (1998), pp. 145-56. 
even bigotry" (365-6). ${ }^{5}$ The Payne decision allows survivors to find a voice in the legal process to express their pain and outrage, but scholars warn that these displays bring emotion rather than reason into the courtroom.

Given this uneasiness, scholars have also asked whether victims really feel better after giving an impact statement. In terms of emotional closure, Andrew Karmen speculates that because the "deprivations endured by an inmate behind bars in no way eliminates the emotional, physical, or financial harm endured by the victim," victims get little satisfaction from "the knowledge that a convict has been punished on their behalf" (162). ${ }^{6}$ Therefore, as Susan Bandes proposes, although a "public, collectivized resolution" can provide some "therapeutic or spiritual closures, the legal system cannot meet victims' needs on a case by case basis" (13). ${ }^{7}$ Conversely, Edwin Villmoare and Virginia Neto found in interviewing 171 victims, "Over half of the victims speaking (54 percent) reported that indeed they felt different after making their statement to the judge, and 59 percent expressed positive feelings of satisfaction or relief" (44). ${ }^{8}$ But it may be judicial response, not a specific effect on the sentence that may bring that satisfaction. Edna Erez, for example, found that "a major source of satisfaction for victims" comes not from any direct effect on the sentence but instead comes "when judges pay attention to their input by citing victims' own phrases from impact statements in judicial sentencing comments" (553). ${ }^{9}$

Finally, scholars have explored whether impact statements have an effect on sentencing. Edith Greene (1999), for example, found that mock jurors who had information about the

5. Susan Bandes, "Empathy, Narrative, and Victim Impact Statements," The University of Chicago Law Review 63 (1996), pp. 361-412. See, also, Gregory B. Schneider, "Victim Impact Statement: A Victim's Steam Valve," Criminal Justice Journal 14 (1992), pp. 407423; Richard Burr, "Litigating with Victim Impact Testimony: The Serendipity That Has Come from Payne v. Tennessee," Cornell Law Review (88), pp. 517-29; and Bruce Arrigo and Christopher R. Williams, "Victim Vices, Victim Voices, and Impact Statements: On the Place of Emotion and the Role of Restorative Justice in Capital Sentencing," Crime \& Delinquency 49 (2003), pp. 603-26.

6. Andrew J. Karmen, "Who's Against Victims' Rights? The Nature of the Opposition to Pro-Victim Initiatives in Criminal Justice," St. John's Journal of Legal Comment 8 (1992), pp. 157-75.

7. Susan Bandes, "When Victims Seek Closure: Forgiveness, Vengeance, and the Role of Government," Fordham Urban Law Journal 27 (2000), pp. 1-14; See, also, Susan W. Hillenbrand and Barbara E. Smith, Victims Rights Legislation: An Assessment of Its Impact on Criminal Justice Practitioners and Victims, Executive Summary, A Study of the American Bar Association, Criminal Justice Section, Victim Witness Project. Funded by the National Institute of Justice, May 1989; and Arrigo and Williams, "Victim Vices."

8. Edwin Villmoare and Virginia V. Neto, Victim Appearances at Sentencing Hearings under the California Victims' Bill of Rights, U. S. Department of Justice, National Institute of Justice. Study undertaken by the Center for Research, McGeorge School of Law, University of the Pacific, March 1987.

9. Edna Erez, "Who's Afraid of the Big Bad Victim? Victim Impact Statements as Victim Empowerment and Enhancement of Justice," Criminal Law Review (July 1999), pp. 545-56. See, also, Edna Erez, Victim Impact Statements, Australian Institute of Criminology: Trends and Issues in Crime and Criminal Justice. Australian Institute of Criminology, GPO Box 2944, Canberra ACT 2601, Australia, no. 33, 1-8, September 1991. 
personal qualities of the deceased; the psychological, financial, and physical effects on the victim's family; and the family's opinions about sentencing "had a more favorable impression" of the victim than those who had only the opinion evidence or who had no victim impact information (344). ${ }^{10}$ Cynthia Ludwig, however, found that impact statements did not have a significant effect on decisions to depart from the presumed sentence, to sentence according to aggravated or mitigated guidelines, or to issue restitution orders. ${ }^{11}$ After interviews with judges and other court officials in Australia, Edna Erez and Kathy Laster, moreover, proposed that victim input "has failed to transform court outcomes and routines," including sentencing in criminal cases because legal practitioners use "techniques of neutralization and efficiency," such as dismissing claims of victims "that they deem unreasonable," to minimize such input (531). ${ }^{12}$ Also, Andrew Sanders, Carolyn Hoyle, Rod Morgan, and Ed Cape explained that impact statements have little effect because most cases are "typical cases," that is, "the impact of the crime on the victim is as one would expect given the nature and seriousness of the crime," and any significant harm will be revealed before the sentencing hearing, in the form of witness statements, for example (454). ${ }^{13}$

In another complication, in many states such as Minnesota, judges must conform to sentencing guidelines in felony cases or justify their departures from them, but no universal guidelines exist on how judges should weigh impact statements during plea negotiations or sentencing decisions. Courts are then challenged because, as John Conley and William O'Barr propose, in impact statements, victims "rely on the conventions of everyday narratives about trouble," rather than on logical hypotheses for testing against facts (56). ${ }^{14}$ Thus, although the courts have decided that impact statements do not violate the

10. Edith Greene, "The Many Guises of Victim Impact Evidence and Effects on Jurors' Judgments," Psychology, Crime \& Law 5 (1999), pp. 331-48. See, also, Greene and Koehring, "Victim Impact Evidence"; and Janice Nadler and Mary R. Rose, "Victim Impact Testimony and the Psychology of Punishment," Cornell Law Review 88 (2003), pp. 419-56.

11. Cynthia G. Ludwig, The Utilization of Victim Impact Statements and Victim Impact Policy and Instrumental Design by the Third Judicial District Court System in Shawnee County, Kansas, Unpublished Masters in Criminal Justice Thesis, Washburn University of Topeka, 2001. See, also, Edna Erez and Pamela Tontodonata, "The Effect of Victim Participation in Sentencing on Sentencing Outcomes," Criminology 28 (1990), pp. 451-74; and Linda Sue Jackson, A Study of the Victim Impact Statement and Its Relationship to Sentence Length in Prince George's County, Maryland, Unpublished Masters in Arts Thesis, Institute of Criminal Justice and Criminology, The University of Maryland, 1994.

12. Edna Erez and Kathy Laster, "Neutralizing Victim Reform: Legal Professionals' Perspectives on Victims and Impact Statements," Crime \& Delinquency 45 (1999), pp. 530-53. See, also, Madeline Henley, Robert C. Davis, and Barbara E. Smith, "The Reactions of Prosecutors and Judges to Victim Impact Statements," International Review of Victimology 3 (1994), pp. 83-93; and Brian Myers and Jack Arbuthnot, "The Effects of Victim Impact Evidence on the Verdicts and Sentencing Judgments of Mock Jurors," Journal of Offender Rehabilitation 29 (1999), pp. 95-112.

13. Andrew Sanders, Carolyn Hoyle, Rod Morgan, and Ed Cape, "Victim Impact Statements: Don't Work, Can't Work," Criminal Law Review (2001), pp. 447-58.

14. John M. Conley and William M. O'Barr, Rules versus Relationships: The Ethnography of Legal Discourse (Chicago: University of Chicago Press, 1990). 
constitutional rights of defendant, we are still unsure as to their effect on sentencing decisions and on the healing process of victims, and judges must, quite often on a very personal level, decide how to strike a balance between the appeals from victims offered in impact statements and the need to follow sentencing guidelines.

To provide additional context to this scholarly and legal conversation about victim impact statements, we need to ask the decision-makers, the judges, how they respond to such statements, particularly those presented orally in sentencing hearings. What do judges say they feel about the place of impact statements, given their emotional content? What do judges say makes an impact statement persuasive? Is there an indication that impact statements are received differently given the nature of the case? And, can we speculate further as to how might judicial reaction affect the sense of inclusion or exclusion that a victim might feel in the legal process?

To begin to answer these questions, we held individual 45-minute, face-to-face conversations with 22 judges in the Fourth Judicial District in Minnesota (Hennepin County-Minneapolis) and 6 judges in the Second Judicial District (Ramsey CountySt. Paul) between November 2004 and May 2006. ${ }^{15}$ We began these conversations by asking about victim impact statements in general, and the judges used examples of general assault, DWI, and homicide cases, particularly among intimates, in their responses. We also asked the judges specifically about their experiences with victim impact statements in domestic violence and sexual assault cases, cases we suspected brought special challenges for judges. ${ }^{16}$ In these conversations, we acknowledge that we captured judicial perceptions and therefore are cautious about generalizations; for example, we cannot trace the effects of these judicial perceptions on courtroom behaviors with any precision. We also did not find any significant distinctions among the judges' perceptions based on sex, age, or ethnicity; however, we do feel comfortable in noting when the majority of judges expressed similar ideas. Our questions to the judges were primarily open-ended because we were interested in what judges in their role of decision-makers think about victim impact statements and the emotions these statements bring into their courtrooms, and in this essay we use descriptive language that reflects the qualitative nature of our investigation. We also attended 17 sentencing hearings in Hennepin County and Ramsey County to understand the courtroom dynamics when an impact statement is offered. We observed hearings in which the perpetrators were charged with the following crimes:

15. In our sample, $60 \%$ of the judges were male, $40 \%$ female; $89 \%$ were Caucasian, $7 \%$ African American, and 4\% Hispanic; $43 \%$ had 5 to 10 years' experience on the bench, $32 \%$ had 20 or more years' experience, and $25 \%$ had 11 to 20 years' experience; finally, current assignments were as follows: $66 \%$ criminal and civil, $17 \%$ juvenile, $7 \%$ civil only, $7 \%$ chief judge, and $3 \%$ family only. About one third of the judges in the Fourth District agreed to meet with us, and about one fourth of the judges in the Second District.

16. During this project we received encouragement and support in this project from WATCH, local volunteer-based court monitoring and research organization that follows family and sexual violence cases and provides feedback to the justice system, and for which one of us had served as a long-time volunteer. This support from WATCH served as a catalyst for the judges agreeing to be interviewed and helped us locate hearings in which impact statements were offered. 
Murder, $1^{\text {st }}$ degree (two counts or cases)

Intentional murder, $2^{\text {nd }}$ degree (one)

Murder, $2^{\text {nd }}$ degree (three)

Unintentional murder, $2^{\text {nd }}$ degree (two)

Manslaughter, $1^{\text {st }}$ degree (one)

Vehicular homicide (one)

Criminal sexual conduct, $1^{\text {st }}$ degree (one)

Criminal sexual conduct, $3^{\text {rd }}$ degree (four)

Attempted criminal sexual conduct, $3^{\text {rd }}$ degree (one)

Assault, $3^{\text {rd }}$ degree (one)

ID theft (one)

Aggravated robbery (one)

Burglary, $1^{\text {st }}$ degree (two)

Burglary, $3^{\text {rd }}$ degree (one)

Gross misdemeanor harassment/stalking (one)

Given that scope and those limitations, we believe that the perceptions the judges offered us add to our understanding of what judges, in their roles as decision-makers, think about victim impact statements and about the emotions these statements bring into their courtrooms and how the specific cases, or those various contexts, inform their reactions to these expressions of emotion. As we explain below, we tackle perceptions through the theoretical lens of emotionology.

\section{Emotionology}

Emotionology is the emotional standards within a culture. These standards dictate what are acceptable emotions and what are unacceptable emotions. Emotionology then places the expressions of these emotions within a hierarchy. Emotionology affects not only evaluation of emotional expressions but also affects behavior as people normalize and internalize such emotional standards. Emotionology is established by members of a culture but is highly influenced by those who are granted a widespread voice, such as the media and law, medicine, or other such powerful voices. Once emotionology is established, it affects personal and social reactions to emotions, is built into institutions, and enforces and sometimes conceals hierarchical relationships. ${ }^{17}$ The study of emotionology, as we apply it in our study, has been refined by sociologists and historians of emotion. The study of emotionology is primarily an interpretative act, examining discourse such as media presentations, literary offerings, prescriptive manuals, professional documents and conversations, and popular culture representations. Such study speculates about the contexts in which and extent to which such emotions as anger, compassion, and grief are considered acceptable in a given time and place. Historian of emotion Peter Stearns, for example, builds upon the concept of "feeling rules," as proposed by sociologist Arlie Hochschild, to analyze the "recommended norms by which people are

17. See Carole Z. Stearns and Peter N. Stearns, Anger: The Struggle for Emotional Control in America's History (Chicago: The University of Chicago Press, 1986), p. 13. 
supposed to shape their emotional expressions and react to the expressions of others" (2). ${ }^{18}$ These scholars of emotionology then generalize about the approval and disapproval of particular emotional expressions throughout the history of a culture or at any one time within that history. The study of emotionology is distinct from empirical psychological studies that might be conducted in a laboratory setting or focus on the biological elements of emotion and from anthropological studies that offer an intense and prolonged look at emotional interactions. Emotionology then, as we apply it and as Carole Stearns and Peter Stearns define it, "governs what people think they should be experiencing"; in other words, even though someone might feel anger, he or she might believe that this anger reflects more a lack of personal control than a genuine dismay. ${ }^{19}$ Again, emotionology also governs our institutions and practices. Therefore, what we find useful to our study is the assumption that "basic emotions are not the whole storythat emotional experience contains a strong cognitive and self-reflective element that is greatly affected by the cultural standards applied to the experience." 20 In addition, we apply the assumptions that emotionology is influenced and reflected by those with powerful voices within a society, such as judges and lawmakers, and that emotionology is reflected in private as well as public settings, such as courtrooms. ${ }^{21}$

Studying our judicial conversations and hearing observations through the lens of emotionology is particularly helpful, because, as Susan Bandes points out, "In the conventional story, emotion has a certain, narrowly defined place in law. It is assigned to criminal courts. It is confined to those-like witnesses, the accused, the public - without legal training" (2). ${ }^{22}$ When we first began our analysis of the judges' perceptions about impact statements, we recognized the distinctions they drew between emotion and reason but then turned to scholarly studies of emotionology to understand the distinctions the judges made among emotions, particularly as those distinctions reflected or reinforced what emotionology scholars propose are contemporary cultural assumptions about emotional expression and control. Therefore, emotionology gives us the tools and vocabulary to interpret what the judges said about the place of emotion in the courtrooms and what we observed in the sentencing hearings.

Again, the study of emotionology suggests that emotional standards not only distinguish among emotions but also value them differently, a concept we found valuable in interpreting what the judges said about displays of anger, compassion, and grief within impact statements. This hierarchy among emotions, scholars like Sara Ahmed find, may, in fact, displace the hierarchy between emotion and reason, as "some emotions

18. Peter N. Stearns, American Cool: Constructing a Twentieth-Century Emotional Style (New York: NYU Press, 1994). See, also, Arlie R. Hochschild, "Emotional Work, Feeling Rules, and Social Structure," American Journal of Sociology 85 (1979), pp. 551-75; and Carole Z. Stearns and Peter N. Stearns, "Introduction," in Carole Z. Stearns and Peter N. Stearns, eds., Emotion and Social Change (New York: Holmes and Meir, 1988), pp. 1-21.

19. Stearns and Stearns, Anger, p. 17.

20. Stearns, American Cool, p. 3.

21. Stearns and Stearns, Anger, p. 14; Stearns, American Cool, p. 15.

22. Susan Bandes, "Introduction," in Susan Bandes, ed., Passions of the Law (New York: NYU Press, 1999), pp. 1-15. 
are 'elevated' as signs of civilization, whilst others remain 'lower' as signs of weaknesses" (3). ${ }^{23}$ At the beginning of the twentieth century, for example, grief became generally a positive and understandable emotion in Western culture. As Martha Nussbaum notes, "Most of us think that it is right to attach great importance to loved ones, and to think such a death terrible" (31-32), but as Peter Stearns finds, beginning at the turn of the last century in the United States, an expectation of control of grief emerged "where intensity might burden not only the individual but also the others exposed, whose whole emotional balance might be thrown off by the effects of untrammeled passion" (190). ${ }^{24}$ Thus, grief is judged not solely according to whether it seems justified or reasonable but also according to whether it disturbs others, so despite a general acceptance of grief, those who express what others define as excessive grief may be judged out of control and immature. Because a great many victim impact statements contain expressions of grief, we looked for judges' expectations as to how much control over grief victims were expected to have and how much tolerance for expressions of grief judges seemed to have.

This expectation of control also appears in the emotionology of anger. As Carole Stearns and Peter Stearns conclude, in contemporary America, "the emotionology of anger has demanded ever more rigorous suppression of the feeling and spread from personal relationships to more public spheres" (215). ${ }^{25}$ As with grief, those who cannot manage anger are considered immature. Dismay and judgment about expressions of anger have, however, "turned to an attempt to undermine the emotional basis for grievance," a finding particularly important to our study of impact statements in which victims often want to justify their grievances based on the emotional effects of the crime. Therefore, in attempting to create within the law a "cool, institutional rationality," anger was viewed as an "internal problem rather than a normal response to external stimulus" and linked to personal revenge. ${ }^{26}$ Thus, we interpreted judicial perceptions and responses to anger according to this speculation that so-called excessive anger is caused by the desire for personal revenge, and personal revenge was contrasted to social retribution. This contrast was illuminated, if not anticipated, by scholarly studies of emotionology. Samuel Pillsbury, for example, argues that retribution "seeks another's suffering, not to satisfy a personal need, but for a principle of good-enforcing respect for persons" (690). ${ }^{27}$ Personal revenge, on the other hand, "arises from a judgment of harm to self

23. Sara Ahmed, The Cultural Politics of Emotion (New York: Routledge, 2004).

24. Martha C. Nussbaum, Upheavals of Thought: The Intelligence of Emotions (Cambridge: Cambridge University Press, 2001); Stearns, American Cool.

25. Stearns and Stearns, Anger; see, also, Stearns, American Cool; Carole Z. Stearns, " "Lord Help Me Walk Humbly': Anger and Sadness in England and America, 1570-1750," in Carole Z. Stearns and Peter N. Stearns, eds., Emotion and Social Change (New York: Holmes and Meir, 1988), pp. 39-69; and Peter N. Stearns, "Anger and American Work: A Twentieth-Century Turning Point," in Stearns and Stearns, eds., Emotion, pp. 123-49.

26. Stearns and Stearns, Anger, pp. 238, 239, emphasis added. See, also, Danielle S. Allen, "Democratic Dis-ease: Of Anger and the Troubling Nature of Punishment," in Bandes, ed., Passions, pp. 191-214.

27. Samuel H. Pillsbury, "Emotional Justice: Moralizing the Passions of Criminal Punishment," Cornell Law Review 74 (1988-1989), pp. 655-710. See, also, Martha C. Nussbaum, Hiding from Humanity: Disgust, Shame, and the Law (Princeton: Princeton University Press, 2004). 
made according to personal principles" where the revenge-seeker is "driven by a personalized vision of victimization" (690). ${ }^{28}$ This distinction sets up why some judges are uncomfortable with expressions of anger in impact statements; as Susan Bandes says, "Perhaps the most explicit recognition of vengeance in the courtroom comes from victim impact statements, in which relatives of murder victims tell the capital jury about the devastation caused by the crime, and in some jurisdictions, about the sentence they would like to see imposed" (2-3). ${ }^{29}$ Therefore, as Martha Minow adds, the criminal justice system seeks "to tame or channel" these feelings of revenge: "It transfers the authority and power to respond to private violence from the victim and the victim's loved ones to the state, and in doing so, cools the likely desire for inflicting comparable harm into a more general commitment to prosecute, and should sufficient evidence be adduced after a fair process, to punish" $(265) .{ }^{30}$ For judges faced with sentencing decisions, retribution may be acceptable or even appropriate in legal settings, but personal revenge is suspect, expressed by an immature person lacking control, a distinction judge may be challenged to discern in a highly angry narrative about the effects of a crime on a person's life.

While anger is often equated with immaturity, inability to reach closure, and personal revenge, and grief may be acceptable as long as it is not excessive, compassion is the emotion "most frequently viewed with approval in the tradition [of Western philosophy], and more frequently taken to provide a good foundation for rational deliberation and appropriate action, in public as well as private life." 31 Bruce Arrigo and Christopher Williams define compassion as understanding the similarities between ourselves and others, a form of identification (615). ${ }^{32}$ The issue of fault and circumstances, however, complicate analysis of expressions of compassion in impact statements. As Martha Nussbaum says, "Insofar as we do feel compassion, it is either because we believe the person to be without blame for her plight or because, though there is an element of fault, we believe that her suffering is out of proportion to the fault" (311). When suffering seems out of proportion to fault, Nussbaum proposes that mercy, or "the inclination of the judgment toward leniency in selecting penalties" (365), might motivate a judge to accept, or a victim in an impact statement to ask for, a downward departure in disposition or duration from sentencing guidelines. ${ }^{33}$ In reality, of course, it may be that a case is too weak to come to trial and so the plea negotiation reflects a compromise that at least gets some time or supervision for the perpetrator. We found, moreover, that judges' tendency to appreciate expressions of compassion might be influenced by those victims who not so much ask for leniency

28. Pillsbury, "Emotional Justice," p. 690. See, also, Bandes, "When Victims Seek Closure," p. 11. 29. Bandes, "Introduction."

30. Martha Minow, "Institutions and Emotions: Redressing Mass Violence," in Bandes, ed. Passions, pp. 265-81.

31. Nussbaum, Upheavals, p. 299.

32. Arrigo and Williams, "Victim Vices." See, also, Elizabeth V.Spelman, Fruits of Sorrow: Framing Our Attention to Suffering (Boston: Beacon Press, 1997); Nussbaum, Upheavals; and Kathleen Woodward, "Calculating Compassion," in Lauren Berlant, ed., Compassion: The Culture and Politics of an Emotion (New York: Routledge, 2004), pp. 59-86.

33. Nussbaum, Upheavals. 
but in expressing compassion for the perpetrator actually bow to the judgment of the court. Thus, we use scholarship on emotionology to help us identify and analyze what judges say about emotion and reason and the hierarchy in which they may place grief, anger, and compassion, the emotions mentioned most frequently by the judges in our conversations with them.

\section{Domestic Violence as a Systemic and Public Problem}

The study of emotionology helps us interpret what we heard in our judicial conversations and in sentencing hearings, but because we ended our judicial conversations by asking judges specifically about the challenges of domestic violence cases, we also take the stance, gathered from current legal and feminist scholarship, that domestic violence is a systemic and public problem rather than a private one. In other words, we assume that judicial perceptions and attitudes must be understood as they reflect and contribute not only to cultural assumptions about emotions but also to gender roles and the agency and power assigned to men and women who express these emotions. Again, we asked the judges specifically about domestic cases because we anticipated that these cases would be most challenging in sorting through emotional expressions. Moreover, examining judges' comments about victim impact statements in domestic violence cases also enables us to understand whether impact statements and the emotional expressions contained within them might be received differently given the nature of the case. Finally, this stance places the problem of domestic violence clearly in the public arena of the courtroom and allows us to speculate about the impact of judicial perception on the problem.

Since the battered women's movement in the 1970s, feminist scholars have urged a focus on power structures rather than on battling couples. ${ }^{34}$ Domestic violence cases, however, remain problematic for courts for a number of reasons. As Lucy Friedman and Minna Shulman note, domestic violence cases are "riddled with evidentiary problems"; victims are "reluctant to testify either because of fear or ambivalence"; and, despite progress, for many involved in such legal proceedings, domestic violence remains "a family and private matter, not a criminal or public one" (95). ${ }^{35}$ Cultural

34. See, for example, Susan Schechter, Women and Male Violence: The Visions and Struggles of the Battered Women's Movement (Cambridge, MA: South End Press, 1982); Liz Kelly, Surviving Sexual Violence (Minneapolis: University of Minnesota Press, 1988); R. Emerson Dobash and Russell P. Dobash, Women, Violence, and Social Change (London: Routledge, 1992); Elizabeth Schneider, Battered Women \& Feminist Lawmaking (New Haven: Yale University Press, 2000); Jennifer L. Hartman and Joanne Belknap, "Beyond the Gatekeepers: Court Professionals' Self-Reported Attitudes about and Experiences with Misdemeanor Domestic Violence Cases," Criminal Justice and Behavior 30 (2003), pp. 349-73; and JoAnn Miller, "A Specification of the Types of Intimate Partner Violence Experienced by Women in the General Population," Violence Against Women 12 (2006), pp. 1105-31.

35. Lucy N. Friedman and Minna Shulman, "Domestic Violence: The Criminal Justice Response," in Arthur Lurigio, Wesley G. Skogan, and Robert C. David, eds., Victims of Crime: Problems, Policies, and Programs (Newbury Park, CA: Sage, 1990), pp. 87-103. 
assumptions about gender roles, moreover, reflect and are reflected within legal measures used to curtail domestic violence and may affect the response of legal professionals to domestic violence victims. As Martha Mahoney states, for example, "[B]oth law and societal perceptions affect women's understandings of our own lives, relationships and options; our lives are part of the culture that affects legal interpretation and within which further legal moves are made" (1). "The responses of court personnel to domestic violence victims then, as well as the very laws that govern the treatment of victims within legal process, are influenced by sociocultural assumptions about the proper roles of women and men and the authority assigned to them given the arguments they make.

Gender assumptions and systemic structures thus often are reflected in judicial reactions to domestic violence cases. In a preliminary study, for example, Patricia Yancey, John Reynolds, and Shelley Keith explore how judges' responses might be influenced by their level of feminist consciousness. The dimensions of a feminist consciousness determine the extent to which court personnel, including judges and attorneys, accept or reject rape myths or "a view that holds women or girls responsible for being raped," attitudes toward domestic violence or "rejection of men's right to harm women partners," and stereotypes of women or "rejection of negative representations of women" (671). ${ }^{37}$ Exploring judicial responses remains difficult because direct access to judges is often limited, and, as Ford, Rompf, Faragher, and Weisenfluh discovered, judges' responses to domestic violence victims vary significantly. ${ }^{38}$ And, yet, capturing a sense of judicial response remains important because as James Ptacek discovered in his study of restraining order hearings, what judges do "becomes part of the ongoing dynamic of battering" (172). ${ }^{39}$ To these explorations of judges' reactions to victims of domestic violence then, we added another necessary complexity: victim impact statements.

Making an impact statement is challenging for the domestic violence victim who may want the violence to stop but the relationship to remain intact, fear retaliation from her abuser, or worry about loss of financial support if he were to be sentenced to prison. Making a statement, on the other hand, may be an important step for many victims in regaining a sense of control over their lives. Such input from a domestic violence victim can be frustrating for court personnel who wonder why she did not leave the relationship before and may not wish to leave now or who witness a victim recant earlier testimony. ${ }^{40}$

36. Martha Mahoney, "Legal Images of Battered Women: Redefining the Issue of Separation," Michigan Law Review 90 (1991), pp. 1, 5-6, 65-76, 78-79.

37. Patricia M. Yancey, John R. Reynolds, and Shelley Keith, "Gender Bias and Feminist Consciousness among Judges and Attorneys: A Standpoint Theory Analysis,” Signs 27 (2002), pp. 665-702.

38. J. Ford, E.L. Rompf, T. Faragher, and S. Weisenfluh, "Case Outcomes in Domestic Violence Court: Influences of Judges," Psychological Reports 77 (1995), pp. 587-95.

39. James Ptacek, Battered Women in the Courtroom: The Power of Judicial Response (Boston: Northeastern Press, 1999).

40. See, for example, Lauren Bennet, Lisa Goodman, and Mary Ann Dutton, "Systemic Obstacles to the Criminal Prosecution of a Battering Partner: A Victim Perspective," Journal of Interpersonal Violence 14 (1999), pp. 761-772; and Hartman and Belknap, "Beyond." 
Moreover, court officials may rely on stereotypes about "good" victims who behave in "appropriate" ways and then become critical of those who do not, and they struggle to resolve the potential conflict between an impulse to protect the victim and the requirement to listen to her requests.

We must then add the lens of gender to our discussion of emotionology, particularly in the case of domestic violence, and we need to "treat each emotion contextually" (30), as Susan Bandes suggests. ${ }^{41}$ Peter Stearns has proposed that women were disadvantaged in the move toward greater uniformity in emotional standards and the shift toward responsiveness to others and therefore "heightened emotional individualism": "Men most clearly moved toward a distaste for emotional exchange on the grounds that individuals should exert self-control, while many women preferred to seek and provide an audience for the verbal venting of intense sentiments" (252, 248). ${ }^{42}$ Female victims of domestic violence, just to suggest one effect of these differences, may benefit most from having an audience for their emotional expressions, a need that may elicit discomfort in those listeners who expect emotional restraint and control.

In this essay then, we convey one set of judges' responses to victim impact statements in general and their descriptions of how they value expressions of the emotions they hear most frequently: grief, anger, and compassion. We also share what we observed in the courtroom when victim impact statements were delivered and judges responded to them. We focus at the end of the essay on the dilemma that judges face when compassion is expressed by victims who are in a relationship with a violent offender. Our goal, through judicial conversations and observations, is to place judicial reactions to impact statements within a cultural as well as legal context and then to point to emotions as expressed in a particular context: judicial construction of the domestic violence victim that in ways may present a double bind, how to protect her and yet to grant her agency.

\section{Emotion and Reason in the Courtroom:The Place of Victim Impact Statements}

You know, the court is there to redress wrongs. And one of the wrongs for victims is emotional distress, and I think that being allowed to make a record on what happened to you and how you feel about it is one way of dealing with the emotional distress. (2JD3) $)^{43}$

Let's say that a man goes into the courtroom, having planned it, and shoots Judge $\mathrm{S}$ _. And another man comes into the courtroom, having planned it, and shoots me. And they are both

41. Bandes, "Introduction."

42. Stearns, American Cool.

43. We identify the speaker of a quote according to the following key: if the speaker is a judge, we identify the district (in this case, the second judicial district is identified by 2JD), and we randomly assign the judge a number (in this case, it is judge number 3). We refer to any hearings observed by the date only to maintain confidentiality of the parties. 
convicted of second-degree murder where the judge has some option as to what the sentence is. And Judge S__ 's wife comes into court and will tell the judge, "Judge, my life is ruined; it will never be the same. I will lose his companionship; I will lose his ability to help finance our household; the children will never see me; he will never see his grandchildren, blah, blah, blah." My wife comes in and says, "Free at last! This is the best thing that ever happened. I can marry my ski instructor; I don't even need to visit the bastard on Memorial Day." Should the sentences be different? Well, I think clearly they shouldn't. (4JD21)

These statements from Minnesota district judges represent reactions to two purposes of victim impact statements - to affect a sentence and to achieve emotional catharsis. Although all the judges we talked with acknowledged the potential emotional value of the impact statement for the victim, many countered that in principle the impact statement should not affect the objectivity and reason necessary for determining a fair and equitable sentence. According to Susan Bandes, however, "the rule of law greatly overstates both the demarcation between the two [emotion and reason] and the possibility of keeping reasoning processes free of emotional variables" (368). ${ }^{44}$ Judges' reliance on legislated state sentencing guidelines and victims' legislated right to articulate the effects of the crime on their lives and react to the disposition of the case seem to exacerbate the perceived conflict between reason and emotion, and the judicial statements about impact statements reflect the perception that emotion and reason should be separate entities. ${ }^{45}$

Because of this perception then, one judge articulated his resentment of the legislative statute that allows victim impact statements, even though he recognized the importance of them to the victim: "I kind of feel like the legislature has pulled kind of a sleight of hand here by saying, 'You are entitled to come in and do this [give an impact statement], but then with a wink and a nod: it's totally meaningless" (4JD9). To this judge, the legislature has, in granting victims the right to give impact statements, set up an impossible task for judges; judges should listen to victim impact statements that may request sentencing conditions particular to a case but must follow standard sentencing guidelines unless they can justify a departure in disposition or duration of a prescribed sentence. There are exceptions, of course; all the judges we talked with could recall a case in which they rethought a sentencing decision or rejected a plea negotiation based on the victim's reaction. But in general, judges, as the one who tried the case of a young girl killed by a stray bullet from a drive-by shooting, agree that to respond to a specific request for

44. Bandes, "Empathy"; see, also, Catherine A. Lutz and Lila Abu-Lughod, "Introduction," in Catherine A. Lutz and Lila Abu-Lughod, eds., Language and the Politics of Emotion (Cambridge: Cambridge University Press, 1990), pp. 1-23; and Sally Engle Merry, "Resistance and the Cultural Power of Law," Law and Society Review 29 (1995), pp. 11-26.

45. During our study the US Supreme Court rendered a decision in Blakely v. Washington 542 U.S. 296; 124 S. Ct. 2531; No. 02-1632 (June 24, 2004), which affects states with sentencing guidelines such as Minnesota. A jury must now determine beyond a reasonable doubt whether aggravating factors, other than prior convictions, exist as "facts" before a judge may use them to depart upward from the sentencing guidelines, or the defendant must waive his "Blakely rights" in a plea negotiation that contains an upward departure. 
sentencing in an impact statement could negate the basic principles of the law. This murder was, according to the judge,

the kind of crime that we as a society are entitled to extract punishment from, and that's the bulk of the reason for most criminal sentencing, why we refer to us as a nation of laws and not individuals ... I think that they [impact statements] had an enormous effect on the people giving them, and I was happy to give them the opportunity to do that. But I think that it would have been completely inappropriate if those statements had impacted sentencing - they shouldn't have. (4JD17)

This expressed distinction between reason and emotion, emphasizing the objectivity and equity built into sentencing guidelines and the standards of the judicial profession, emerged as judges described their reactions to the emotional expressions in a victim impact statement. ${ }^{46}$ As we illustrate below, the judges we talked with expressed the need to maintain authority in the courtroom balanced with their sensitivity to the victim's feelings by alluding to three related rhetorical strategies in delivering a sentence; they stressed to victims that they had a limited range of options in deciding upon a sentence or accepting a plea negotiation; they spoke in what could be termed the language of certainty or inevitability; and they often tried to control their own emotional affect when listening to impact statements.

In terms of the first rhetorical strategy, judges often explained in great length how their choices in terms of the duration and disposition of a sentence were limited by the sentencing guidelines. One judge worried, for example, that he might be seen as "turning down" the victim when he did not adjust the sentence based on the impact statement and so stated that he explained to victims his limited options:

If someone has committed a very violent act towards an innocent victim I am going to give them the maximum I can give them anyway ... but sometimes I have a concern ... that they're [victims] given misinformation or false expectations of what impact that's going to have ... I say, "I cannot do what you are asking. Where in the world did you get the idea I could do that?" (4JD9)

For this judge then, judicial authority rested in not responding to emotional expressions, in not granting the appeals of an impact statement but not openly turning them down either, a stance justified by limited choices.

The second rhetorical strategy, speaking in terms of certainty or inevitability, often seemed to provide further warrant for the first strategy. To avoid the perception that judges are responding to emotional appeals then, they may, Susan Bandes points out, choose to "speak declaratively, in the language of certainty" or exercise a "rhetoric of inevitability, a rhetoric which admits no freedom of choice on the part of the judge" (378). ${ }^{47}$ And, so, one judge said, "But I also am very careful to tell them that "the decision

46. Minnesota sentencing guidelines can be found at $<\mathrm{http} / /$ www.msgc.state.mn.us/msgc5/ guidelines.htm>.

47. Bandes, "Empathy"; see, also, Catherine Lutz, Unnatural Emotions: Everyday Sentiments on a Micronesian Atoll \& Their Challenge to Western Theory (Chicago: University of Chicago Press, 1988). 
is mine, and it's [the victim impact statement] one of many factors, and if you are disappointed in how it comes out, it's because there are so many other factors I have to weigh"" (4JD2). Judges may feel compelled to explain directly to victims where authority lies in the courtroom regardless of their consideration of an impact statement by, for example, limiting the number of impact statements or the time spent on them in any particular hearing. As one judge said, "What I object to is when I have set up something for a 30-minute hearing, and the prosecutor tells me, 'We have 12 victims that are going to make statements.' I say, 'No, you are not. You are going to have two or three'" (4JD9). And so judges may assert their authority in the courtroom and yet describe how their choices in sentencing are limited by the law. To some judges, a stance other than this one invites criticism from victims: "No matter what you do, somebody is going to think, "that was a terrible judge"" (4JD22).

Finally, while judges may accept the emotional benefit to victims, they may also feel the need to conceal how the emotions conveyed in impact statements can affect them or suffer loss of authority. This third rhetorical strategy then might be to suppress their own emotional affect. One judge, for example, recalled a DWI case in which a young child almost lost his life. His mother delivered an impact statement in which she described how she thought her son was going to die. "I remember thinking," the judge said, "I am going to cry." But he regained what he thought was necessary composure because "you are not supposed to cry on the bench if you are a judge" (4JD3). This last strategy, however, masking emotional affect to maintain courtroom authority, judges may describe as an unfortunate result and so worry about the complete negation of judicial emotion. In essence, the emotional work to maintain an objective demeanor may lead to emotional detachment. Judges described, for example, being "sort of insulated and numb in a sense" (4JD20) from handling so many serious cases, "so removed from crime for the most part" (4JD2) in their own personal lives, and working in a legal tradition that tends "to strip away emotions" (4JD6) and becomes "a factory of sorts where we are just grinding these cases out" (4JD20). This response is a survival tactic for some; one judge said, "I think I am able to put things behind me in order to just keep living. I seem to be able to finish something and be done with it and not have it haunt me too long" (4JD2). But judges did worry about this numbing effect, regardless of whether it is cultivated deliberately. As one judge said, "The best thing for judges would be if we could be victims ourselves ... or have our families be victims and come out whole" (4JD2). As "powerfully painful" as impact statements can be then, as another judge said, they are "constructive in the sense of bringing some reality into the room" (4JD6).

Overall, most of the judges we spoke with did not want victims to avoid hearings because they think that their statements will make no difference, and the judges expressed the burden of having victims leave court feeling that their opinions about the sentence had no effect, a feeling that could counter any opportunity for catharsis. But the judges also felt the need to maintain their authority within the courtroom, a need expressed in their descriptions of the conflict between reason and emotion, and they particularly perceived that reaction to emotional expression and appeal could undermine that authority, coming perhaps at a cost when judges become emotionally numb. They adopted then rhetorical strategies to explain their limited options by the language 
of inevitability and masked or negated their own emotional affect. Thus, the emotionology of the law for the judges we talked with distinguished between emotion and reason, elevating reason to a higher level than emotion and to a great extent modeling cultural emotionology, but for a specific purpose: to manage authority while at the same time not denying agency to victims. This emotionology, when weighing sentencing guidelines used to achieve consistency and equity against the right to give an impact statement to achieve catharsis and to affect the sentence, granted greater value to reason than to emotion. If this hierarchy is indeed embedded in our cultural emotionology, then readjustment in any arena might be hard to achieve.

\section{Grief as an Acceptable Emotion in the Courtroom: Permission to Cry but Not Too Much}

You can really have the empathy; you can feel the pain. But again, our justice system with the sentencing guidelines really does take out your visceral reactions to things. (2JD1)

In a couple of murder cases, I have had victim impact statements that have lasted an hour, hour and a half, because there are five or six people. All the relatives chime in. ... But they bring pictures, and in one case they showed a video. You know, it's kind of a secular funeral. (4JD21)

Although it did not seem unusual to the judges we spoke with for the victim or the victim's family to want to share their grief, many judges felt that their reactions to these expressions of emotion must be curtailed to do their job properly, and they sensed a point where expressions of grief become excessive. Thus, again the judges' valuing of expressions of grief reflected that expectation of control contained within our cultural emotionology. Once again, this boundary seems to be crossed when judges perceive they have lost control of their own courtrooms. One judge, in an extreme example, told of having to stop family members who brought in the victim's ashes and started to "sprinkle them in the room" (4JD11). As Arlie Hochschild explains, "We can offend against a feeling rule when we grieve too much or too little, when we overmanage or undermanage grief" (emphasis in original, 64). ${ }^{48}$ Emotionology in the courtroom then includes acceptance of managed and "reasonable" expressions of grief, and the responsibility of that management rests on the shoulders of the victim until judges feel they must step in to curtail the victim's speech or actions. Here again then cultural emotionology is bolstered by the perceived need for judicial control and authority.

To inform this understanding of the perception among the judges that grief is understandable although it may need to be managed, we note in particular two judges who, during hearings we attended, acknowledged such grief while imposing the sentence; in

48. Arlie Russell Hochschild, The Managed Heart: Commercialization of Human Feeling (Berkeley: University of California Press, 2003); see, also, Stearns, American Cool; and Spelman, Fruits of Sorrow. 
fact, one added to the conditions of the sentence based on the victim impact statement. In a second-degree murder case, involving again a woman killed by her former boyfriend, the victim's brother told of learning of his sister's death from a cousin who arrived at his door with her scarf worn upside down, within his Ethiopian culture a sign of the death of someone close $(3 / 20 / 06)$. The brother told of his mother, ill with diabetes, asking him to bring his sister home with him on his next visit. When he arrived home with his sister's casket, his mother said, "I didn't tell you to bring her home dead." In imposing the sentence, the judge said he could offer "no words as powerful as those given in the impact statements." He expressed that, on "this day in early spring," he would like to think that the victim "is in the flowers, each blade of grass, the air and sunshine," and assured the family that "she will live in the hearts of those who love her." The judge imposed the standard sentence of 360 months, but first in terms of the number of minutes, then days, then months, and finally years, and then said that he hoped that thoughts of the victim would "occupy every waking hour" of the defendant. In another example, in a seconddegree unintentional homicide case, the victim was shot and left to die in her car by her former boyfriend (4/10/06). In this case, the judge departed upward from the sentencing guidelines because of the defendant's cruelty in failing to render the victim aid and in violating her zone of privacy in shooting her in her own car. The victim's mother described how she prepared her daughter for her funeral because she "didn't want anyone else to touch her child." The judge allowed the mother and former husband of the victim to speak freely of their grief, only admonishing them to direct their comments to her rather than to the defendant. Moreover, when the judge heard, in the impact statements, about the effects on the victim's children, who had been separated to live with different relatives, the judge added restitution for their future counseling to the sentence. These two judges affirmed the reasonableness and necessity of victims' expressing grief. There are judges, of course, at the other end of the spectrum, who acknowledge impact statements with a simple "thank you" or "ok" and do not mention the impact statements when imposing a sentence. After hearing two impact statements in a second-degree murder case in which a husband had killed his wife and after having looked through pictures of the victim provided by her relatives who offered impact statements, for example, one judge merely asked if anyone else wished to speak and then said "ok" and imposed the sentence $(5 / 15 / 06)$.

In our observations then, judges varied in their responses to these expressions of grief in imposing sentences, but in our conversations, the majority of judges said that they tolerated them as long as they were not excessive and might refer to victims' grief in delivering a sentence. We speculate, however, that judicial reaction to grief must be contextualized according to the case. Expressing grief over the loss of a relationship, for example, may aid the domestic violence victim's healing process, but judges did not use these cases to exemplify their responses to necessary expressions of grief; they focused primarily on the loss of life and expressed a general tolerance for those expressions of grief. As with the distinctions between reason and emotion, the judges' attitudes toward grief reflect overall cultural emotionology; in these cases then, victims might feel their grief doubly validated when judges incorporated victims' expressions in delivering a sentence. 


\section{Anger as an Unacceptable Emotion in the Courtroom: The "Lock Them Up and Throw Away the Key" Stuff}

A lot of times they are very vengeful statements. I guess I can understand why somebody would write a statement like that, but when it's merely to spew some venom because they are upset, it's not very helpful. (2JD3)

I just said to her, "You have another, your little boy is here; if you can find it in your heart to, you know, not live with your anger because he needs you too." ... Well, she flipped out. I don't know what she thought, that I was making light of it. Oh, she just flipped out. (4JD11)

Like the two judges quoted above, many of the judges we talked with found anger, particularly when a reflection of personal revenge, an unwelcome, uncomfortable, and unproductive emotion in the courtroom. While some studies of anger indicate that those who express anger may be perceived as more competent, effective, and deserving of higher status than those who do not, the judges we talked with uniformly described anger as an unwelcome emotion in their courtrooms, placing anger toward the bottom of the emotionology hierarchy, as reflected in general cultural emotionology, and distinguished between revenge, sought by the angry victim, and moral outrage, often reserved for the court. 49

The judges we talked with also were dismayed when anger felt misdirected, for example, if a victim became angry with them or they became angry themselves, and victims or victim's families who expressed anger in their impact statements were sometimes perceived as dishonest, out of control, or unable to gain perspective on the crime.

Judges do, of course, seem to understand expressions of anger. As one judge noted, "You know sometimes what we have is more in the nature of ... the bad part of a Greek tragedy, with people absolutely incoherent with grief and anger" (4JD6). Despite this understanding, almost all of the judges we talked with characterized expressions of anger as unproductive. As one said, "If a judge asks, 'what is it that you really want the court to do?' and the answer is 'lock him up forever,' or the answer is something completely contradictory of what the negotiation is, that can create a very awkward situation" (4JD13). In describing victims' reactions to rape or other violent crimes, another judge said that if victims "had their way, the defendant would be lowered one inch at a time into a wood chipper" (4JD9). "“The lock them up and throw away the key' stuff," this judge said, "doesn't really have any impact on me at all because I am already aware of all that" (4JD9). Nevertheless, victims do continue to justify their requests for punishment based on a sense of revenge and a judgment of the evil nature of the perpetrator. In a sentencing hearing for a defendant who had killed a man and who had kidnapped, sexually assaulted, and attempted to murder the man's girlfriend, for example, the girlfriend offered a victim impact statement. She recalled her boyfriend's last words as "Please don't hurt us," and

49. For studies that identify anger with higher status, see, for example, Larissa Z. Tiedens, "Anger and Advancement versus Sadness and Subjugation: The Effects of Negative Emotion Expressions on Social Status Conferral," Journal of Personality and Social Psychology 80 (2001), pp. 86-94. 
described how fearful she still was. She closed her statement with these words: "The time has come to lock Satan up" (5/26/06).

Judges may then, in justifying their discomfort with anger, characterize the victim who expresses or cannot control anger as dishonest or as unwilling or unable to gain perspective on the crime. One judge put it this way: "Honesty. That's the simplest way I can describe it. People get up, and I can tell that they are overstating something, or they have a vengeful purpose behind it, or they want the world and in particular the defendant to be responsible for all their life's problems" (2JD3). Another judge agreed: Excessive anger "can certainly backfire in the sense of the judge's reaction because sometimes victims don't understand that their hatred of the defendant will convey itself to the judge which undermines the credibility of what they are saying in sense of the objectivity" (4JD15). Again judges at times explain why they cannot honor these expressions of anger based on a need to maintain authority. In a hearing for third-degree sexual conduct, for example, involving a minor who was assaulted by a family friend, the young man's parents requested an upward departure from the sentencing guidelines - more jail time and no work release $(2 / 12 / 06)$. The judge explained that he was influenced by the psych evaluation and the pre-sentencing investigation report. "Judges do not make these decisions lightly," he told the family; "in this imperfect world," however, he hoped that the passage of time would help them heal.

Finally, such extreme or out-of-control anger can be misdirected. According to one judge, "The one thing that you see occasionally which I think is unfortunate is sort of the transfer of anger from being angry at the perpetrator to being angry at the court" (4JD10). And, judges who express their own anger toward a defendant are also uneasy about lack of control. One judge, for example, graphically described his own anger at one defendant who continued to show disrespect for the victim and to curse the judge:

I said, "Sir, you are going to prison, and that's where animals like you belong." And I usually don't say that but if you get called a MF [expletive abbreviated] ten times, and it was by someone who raped a step-daughter, and he's in your face ... And I felt bad later. I thought, "Ok, you lost your cool." But I didn't feel that badly, but I try not to stoop to their level. I felt badgood. (4JD22)

For some judges then, expressions of so-called excessive anger, like excessive expressions of grief, threaten judicial control of the courtroom or their neutral personae.

Once again, judges did not use examples from domestic violence cases specifically in discussing anger, but we speculate that this aspect of the emotionology may negatively affect the domestic violence victim, as we will explore in the next sections of this essay. Therefore, in their victim impact statements, domestic violence victims who might need to express their anger, just as their grief, as a necessary step to healing face an emotionology that may question their credibility or feel that they are out of control or lack perspective. Moreover, if gender assumptions prevail, as Peter Stearns speculates, the primarily female victims of domestic violence might not encounter a courtroom that welcomes emoting that anger. ${ }^{50}$

50. Stearns, American Cool. 


\section{Compassion as a Celebrated Emotion in the Courtroom: The Wise and Cooperative Victim}

I just think we probably are all a little more comfortable if we hear the victim say, "This was awful, terrible, and yet I know that society would be better off, or the next set of victims would be better off, or whatever, if this guy gets treatment as opposed to getting prison." (4JD10)

Just as cultural emotionology identifies compassion as one of the "good" emotions, the emotionology of the courtroom does too: the judges we talked with described compassion as requiring a higher level of insight and growth. Expressions of compassion might take into account not only a person's circumstances and degree of suffering regardless of fault but also the goals and means of the justice system. One judge, for example, offered this admiration for compassion: "I am always amazed at how compassionate the victims are. ... Defendants often times speak so poorly of humanity, and the victims speak so well of it" (4JD2). Another judge described a victim of sexual assault who seemed credible because of her ability to achieve perspective in accepting the plea negotiation: "It persuaded me that she knew what she was doing. ... She was thinking now where does this fit for women, and where does this fit for the citizenry and the safety of people in the streets" (4JD10). Because a great many judges mentioned public safety as one of the most important factors they considered in deciding upon a sentence, this victim would be in line with the goals and means of justice, and she is admired by the court for understanding the terms of a plea negotiation that perhaps includes closely supervised probation with treatment rather than jail time will best curtail future violent acts from this perpetrator. However, this ability to express compassion is quite often perceived as the ability to move beyond the personal effects of the crime, as one judge recalled in one family's impact statement in a murder case: "There is nothing that will bring him back, and there is really nothing else that we can do but we appreciate being able to see the system work' ... where people somehow transcend that initial piece are really amazing" (4JD7). Judges express relief if the victims do not oppose a sentence or plea negotiation or if they avoid expressing anger and perhaps if they are even moved to feel compassion for the defendant. If victims can "transcend" beyond a focus on their personal loss and revenge and focus instead on the goals of the court, judges may also be relieved as their authority is reinforced, their decisions not challenged, and their courtrooms under control. Imposing these "feeling rules" on victims, however, might silence those who need to express so-called "bad" emotions to heal.

Compassion in general then is appreciated within the emotionology of the court. Its expression is persuasive to and memorable for many judges as they link it to transcending the individual effects of the crime and to understanding and cooperating with the goals and means of the justice system. Compassionate victims do not seek revenge according to judges' perceptions; they accept the limitations of sentencing guidelines and the inevitability of plea negotiations. Their requests for mercy are interpreted as cooperative, a possible indication of how plea negotiations settle for the lower end of options in sentencing guidelines grids, an interpretation supported by emotionology in the courtroom and in general culture. Moreover, expressions of compassion might be so valued also because they are not often seen. As one judge said, "Once you have been victimized, 
I think you know people aren't so willing to separate the behavior from the person, and they want the person to be accountable" (4JD20).

\section{Compassion as a Suspect Emotion in the Courtroom: The Domestic Violence Victim}

I have women who have had their noses broken and clumps of hair pulled out standing right in front of me, as far away as you are, telling me they are not afraid. It's crazy. And, it's just horribly frustrating. And I will look them right in the eye and tell them, "I don't think that you are making good decisions for yourself, and I will not lift that no-contact order." And they probably hate me for that. (4JD20)

It's usually easier to understand the dynamics ... in a pure sexual assault case. Usually the victim had nothing to do with causing the incident. (2JD3)

Although the emotionology of the courtroom may inspire admiration for victims who express compassion, domestic violence victims who ask for contact with or mercy for the defendant are often suspect, as we see in the first quote above. In general we found that judges who were comfortable with expressions of compassion by victims who are strangers to the perpetrator were uncomfortable with expressions of compassion by victims who are in a relationship with the perpetrator. Their reactions, of course, must be framed in their worry about future victims of the sexual assailant but about not the specific victim who delivered the impact statement; this reaction must be contrasted to their worry about the victim of domestic violence who might remain in imminent danger from this specific assailant. Thus, their explanations as to why these domestic violence victims might lack credibility must be seen in light of the need to protect this victim from this assailant.

Such a protective role, however, as Susan Schechter explains, strips the victim of her agency: "Advocates for this position believe that battered women must decide how to proceed. The essence of victimization is to strip women of control, and the criminal justice system cannot be given powers to further deny women control" (175). ${ }^{51}$ Elaine Chiu proposes that battered women in fact exercise more agency in other aspects of their lives than they are given credit for. ${ }^{52}$ Although an abused woman cannot control the abuse, she is constantly making decisions from ensuring the wellbeing of a child to determining when to seek medical attention for injuries or when to continue working outside the home. Because she may know that she will be denied agency when she enters the justice system, she may be reluctant to do so. Again, the challenge for judges in these cases is to find a way not to silence the domestic violence victim who, in her impact statement, pleads for compassion for her abuser or asks for specific conditions be added to the sentence to allow the relationship to heal; at the same time judges must find a way to protect her as she remains vulnerable to danger because of the very fact of that relationship. For many judges

51. Schechter, Women and Male Violence.

52. Elaine Chiu, "Confronting the Agency in Battered Mothers," Southern California Law Review 74 (2001), pp. 1223-73. 
struggling to meet this challenge, by the nature of the case, the domestic violence victim cannot be seen as transcending the crime in the same ways that a victim not in relationship with the defendant might. Therefore, the possibility of healing by giving an impact statement then might be severely limited for the domestic violence victim, and judges face quite a dilemma in reconciling a victim's requests with judicial need to maintain safety, in this case in the home. It is in this light - the need to protect the domestic violence victim from escalating violence and possible death - that we must understand judges' reactions to her impact statement. Certainly scholars for decades have identified this silencing of domestic violence victims; we expose here another, perhaps hidden aspect of the problem: the truth tests this victim faces when giving an impact statement.

In explaining why expressions of compassion made by victims of domestic violence are suspect, some judges portrayed these victims as having complicity in the crime, as the second judge quoted above implies, particularly in contrast to the "innocent" sexual assault victim, and therefore to gain credibility they often must admit that complicity. Any plea by this victim then may be seen not as an expression of compassion or reluctance to end an intimate relationship if only the violence would stop but rather as weakness or part of her "sickness" as a domestic violence victim caught in the so-called battered-woman syndrome. As Cheryl Hanna proposes, to some judges and prosecutors, "the battered woman and her reactions to the violence are 'unexplainable' unless she is somehow suffering from emotional or psychological problems" (1578). ${ }^{53}$ Some judges then may focus on the victim's perceived limitations rather than the limitations of the system to curtail domestic violence.

One judge we talked with, for example, speculated that domestic violence victims have such "serious emotional disorders" that "they feel more comfortable in that kind of relationship than they would in a more so-called healthy relationship where it would be very difficult for them to function" (2JD5). Another judge proposed that such women are targeted by an abuser: "A lot of people who are victimized are chosen by their victimizers because they are vulnerable people to begin with and the last thing they have the strength to do is to stand up in open court and say what happened" (4JD19). And, as yet another judge said, "You end up with some victims ... who have a history of being unloved, and who are having a hard time making a go of relationship or whatever and so they end up with "bad love"" (4JD10). Judges then may perceive that abused women have "found it very, very difficult to disentangle themselves. They don't have strong backbones in terms of these perpetrators" (4JD20). Thus, the domestic violence victim who expresses compassion in her impact statement, in contrast to victims of other crimes, may be seen not as wise and cooperative but as simply "sick." In essence, she may be further victimized by the court, despite participating in a process that is designed to give her a voice, and her problem may be perceived as a private one.

Moreover, Edna Erez and Linda Rogers note that a perception of the " normal' victim constitutes an important measure against which judges and other legal professionals evaluate victims and the veracity of their impact statements"; this perception includes the "normal" victim's "emotional and psychological reactions to violations of property and

53. Cheryl Hanna, "The Paradox of Hope: The Crime and Punishment of Domestic Violence," William \& Mary Law Review 39 (1997-1998), pp. 1505-84. 
person" (225). ${ }^{54}$ Lynn Hecht Schafron furthers this notion: "The 'true' victim displays just the right amount of tears. No tears and the assumption is that nothing happened to her. Too many tears or an exhibition of anger and the assumption is that she is hysterical and thus noncredible [sic]" (451). ${ }^{55}$ To add to this impulse, because of what they perceive as a lack of credibility, again judges may impose upon the victim of domestic violence a higher test for truth.

One judge we talked with, for example, summed up this common suspicion of the victim: "The factors that make them not want to cooperate with the prosecutor or to not report, they are still at play at the time of sentencing ... I might listen to her and respect her when she says it, but may not do it, or feel that she is in a good position to speak about what is actually in her own best interests" (4JD12). The victim who recants may be a "true" victim as one judge described, "the meek little woman with scars on her face" opposed to the "giant hulking, scowling man," or "the initial report was false because she was mad" (4JD15). But, as this judge says, "We cannot figure those cases out. In those, you know that the victim has lied on one or the other of those occasions" (4JD15). The physical or eyewitness evidence in a domestic violence case often then is considered more reliable than a victim's testimony. As one judge said, "You know you have read that there is a clump of bloody hair left on the carpet and then here's the person saying that it's all a lie, he's a wonderful guy, and the police are the bad people" (4JD20). New laws allow prosecution based on police reports alone, which may help the victim who is afraid to testify, but again the victim of domestic violence enters a courtroom in which she may have almost no credibility in pleading for mercy or expressing compassion in trying to find a way for the relationship to heal because judges anticipate that the "true" victim would focus on the danger she is in unless her sickness, her limitations, prevent her from doing so.

Faced with this dilemma, some judges do acknowledge the limitations of the system and thus feel they cannot successfully intervene in an intimate relationship: "And so in a domestic I have got a person who cannot reconcile her awareness of the defendant's good points with her belief that someone who is guilty of what he has been convicted of has to have no good points and be really evil" (4JD6). Judges may feel helpless in resolving such cases: "So she was pleading for him. You know, there was a reason that he tore the phone out of the wall, that he pitched the batteries and broke the phone, and it was all her fault ... so it gets very confusing. And I think that the court system is a very hard place to resolve the conflicts that are often years in the making" (4JD8). Leonore Simon proposes that, despite these problems, the domestic violence victim may benefit greatly from the prosecution of her case: "Allowing the victim to take an active part in the prosecution of the offender can also result in feelings of empowerment for her that can alter the balance

54. Edna Erez and Linda Rogers, "Victim Impact Statements and Sentencing Outcomes and Processes: The Perspective of Legal Professionals," British Journal of Criminology 39 (1999), pp. 216-39.

55. Lynn Hecht Schafron, "Maiming the Soul: Judges, Sentencing and the Myth of the Nonviolence Rapist," Fordham Urban Law Journal 20 (1993), pp. 438-53; see, also, Amanda Konradi, "Understanding Rape Survivors' Preparations for Court," Violence Against Women 2 (1996), pp. 25-62; and Hartman and Belknap, "Beyond the Gatekeepers." 
of power in the battering relationship and lower rates of future violence" $(273) .{ }^{56}$ One judge described the domestic violence victim's dilemma as follows:

You know if you take the area of domestic abuse, if the victim says that she ... wants punishment, the county attorney says, "That's rational." If she says she wants leniency, the county attorney says, "Discount that because she is being abused and this is part of the cycle of violence and you shouldn't listen to her." Ok, well, that's true in some instances, but I mean the paradigm doesn't work. (4JD3)

That participation may allow her to find a voice in the presence of her abuser, but again that voice may be silenced if her recantation or expression of compassion is automatically seen as unreasonable and if the judge perceives that protecting her from danger outweighs any agency she might be denied.

More specifically, we found in our conversations with judges, the domestic violence victim who expresses compassion or asks for mercy for the perpetrator is granted credibility if she is also in the process of leaving her abuser, displays insight into her relationship and the cycle of violence, takes responsibility for what is perceived as her role in the abuse, or makes specific suggestions on how to protect her own safety. As Martha Mahoney recognized, the time when an abused woman is in the process of leaving is the most dangerous time for her in terms of "separation assault" or "the attack on the woman's body and volition in which her partner seeks to prevent her from leaving, retaliate for separation, or force her to return" (6) ${ }^{57}$ But some judges still look for some evidence that the victim is ready to leave her abuser. As one judge reflected, "I don't know what I can say. Two hundred million two hundred thousand more people that you could be going with [than the defendant]" (4JD11). And, another judge's language belied his sympathy for the victim in saying that the victim was responsible "in a broad sense if she goes back to the abuser" but not in a criminal sense: "[T]hat doesn't mean you give the abuser a pass just because she is stupid enough to go back to him" (4JD21).

Despite these common worries about the defendant continuing his violent acts, some judges grant agency to the victim who pleads for compassion if she displays what they perceive as insight into the relationship or complicity in the abuse. One judge, for example, mentioned that she would be convinced by a victim's ability to reflect on her own responsibility for the violent relationship:

56. Leonore M. J. Simon, "Therapeutic Jurisprudence Approach to the Legal Processing of Domestic Violence Cases," in David B. Wexler and Bruce J. Winick, eds., Law in a Therapeutic Key: Developments in Therapeutic Jurisprudence (Durham, NC: Carolina Academic Press, 1996), pp. 243-85; see, also, Deborah Epstein, "Effective Intervention in Domestic Violence Cases: Rethinking the Roles of Prosecutors, Judges, and the Court System," Yale Journal of Law and Feminism 11 (1999), 3.

57. Mahoney, "Legal Images"; see, also, Edna Erez and Tammy A. King, "Patriarchal Terrorism or Common Couple Violence: Attorneys' Views of Prosecuting and Defending Woman Batterers," in Edna Erez and Kathy Laster, eds., Domestic Violence: Global Responses (Bicester, UK: A. B. Academic, 2000), pp. 207-26. 
Someone sits here and says, "You know, I instigated this, and I was at fault too, which does not exonerate their [the defendant's] response, but I want you to know that I realize that I participated and am taking responsibility for my part in this and will participate in counseling or whatever, to not kind of set things up to end up this way," I think that that is important. (4JD8)

Another judge described a 15-page impact statement that "brought the wheels of justice to a screeching halt": "And I remember being so impressed at how candid this woman is. She talked about her own drug use and her own prostitution, her own history of some petty thefts" (4JD13). While most judges continually struggle with how to help the domestic violence victim, the victim who expresses complicity before some judges may gain credibility in her impact statements. The domestic violence victim who displays insight into how to protect her own safety may also be considered credible by a judge. Even if the domestic violence victim does not want to leave the relationship, she may persuade the judge as to how to keep that relationship safe: "[I]f the victim is saying, 'I am not afraid of him, but I don't want him back in this house until he has completed counseling and a program and unless he is sober.' I mean those things make sense" (4JD20). This victim's requests were made a condition of probation.

In constructing this image of the domestic violence victim, again judges may contrast the domestic violence victim to the sexual assault victim, particularly the victim of stranger rape. As scholars have pointed out, this is not a unique phenomenon. Amanda Konradi, for example, says that common cultural notions depict rape as "an exceedingly violent assault carried out by a stranger" in which "an overwhelmed woman, despite her mental and physical anguish, reports to the police just as soon as she is out of harm's way" (43). ${ }^{58}$ One judge, for example, contrasted "the woman who is a victim of date rape because she excessively consumed alcohol" to someone who had "no ability to control the circumstances" where the perpetrator had a weapon or took her off the streets (4JD10). We also observed this distinction in a hearing for third-degree sexual assault before another judge (4/13/06). Both victim and defendant were teenagers, and both were drinking at a party. In imposing the sentence, the judge twice assured the victim that she "shouldn't be punished" by her teachers and peers for her absences from school as she recovered from her experience. Another judge described the victim of sexual assault as wanting such assurances as offered by the judge in the hearing mentioned above: "They want to know why, especially with sexual assault. 'Is it my fault you did this?' and they want to hear them [defendants] say they are sorry" (2JD4). This judge mentioned sexual assault victims then are differently motivated in their impact statements. In a way, they are allowed to express anger because of their "innocence" as victims: "I think that there is some real truth to the fact that the domestic violence victim loves their perpetrator. And sometimes they want to come as a show of support. ... For sexual assault, it's

58. Konradi, "Understanding"; see, also, Schneider, "Victim Impact Statement"; Jennifer K. Wood, "'In Whose Name': Crime Victim Policy and the Punishing Power of Protection," National Women's Studies Journal 17 (2005), pp. 1-17; and Jeffrey W. Spears, "Prosecution of Sex Crimes," in Frances P. Reddington and Betsy Wright Kreisel, eds., Sexual Assault: The Victims, the Perpetrators, and the Criminal Justice System (Durham, NC: Carolina Academic Press, 2005), pp. 281-97. 
often healing to be able ... to speak to the judge, and [say] you want an eye for an eye or something" (2JD4).

The victim of sexual assault, particularly in a stranger rape, gains credibility in her impact statement in a very different but also challenging way than the victim of domestic violence. To affect the sentencing decision or plea negotiation, the victim of sexual assault needs to prove that she suffered more than the "average" rape victim. She meets this challenge through her narrative skills, however, rather than admitting complicity or providing insight into a "sick" relationship. One of the "hardest things about the guidelines," said one judge, is to "look over the bench and say [figuratively], 'Madam, your rape was just average"" (4JD10). The judge who proposed that a victim would have to persuade him in her impact statement that her rape was not the "average rape," demonstrated this requirement in a hypothetical case: "And I want to hear it in human terms ... 'he used a [brownhandled] knife and so now I have had to go to all white-handled knives, or every time I go into a restaurant or go to Cattle Company, and they give me a brown-handled knife, you know, the thing goes zipping through me again"' (4JD10). Finally, in a sentencing hearing for a stranger assault, for example, we observed the judge issue an upward departure of 80 months, noting that there was a violation of the zone of privacy (the crime took place in the victim's bedroom), and that the incident put other people at risk. When the judge described his reasons for an upward departure, he also noted the content of the impact statement, in which the victim described feeling very vulnerable, suffering from PTSD, having flashbacks, being constantly paranoid, and being unable to trust people (7/28/05).

We see then through the theoretical lens of emotionology that the domestic violence victim who expresses compassion, recants her testimony, or asks for mercy for the defendant is granted little agency. Judicial construction of the sexual assault victim, particularly of stranger rape, may provide an unfortunate contrast to the domestic violence victim. Even if the victim of stranger assault was drinking at the time or on a date with the defendant, judges attempt to affirm her innocence. The sexual violence victim gains credibility, perhaps to argue for upward departure of sentencing guidelines, moreover, if she is able to so describe the effects of the crime on her life to distinguish her assault from the average one. She is not expected to express compassion, but if she does, she is admired for achieving a "world view" of the crime. As we stated earlier, judges must, of course, give primacy to their responsibility to protect the domestic violence victim despite her requests to have contact with the defendant or continue her relationship with him. We do not argue at all with this impulse. We wonder to what extent many of the judges' responses to expressions of compassion and other emotions in these cases are simply rationalizations; the driving force might be simply the fear that the abuser's next assault will be fatal to this victim. But we worry about the judicial choices to grant credibility to the victim of domestic violence if she seems ready to leave the relationship, a most vulnerable time for her. We also wonder how many domestic violence victims who speak at sentencing hearings are at the stage in healing where they can offer insight into the cycle of violence, or we worry about credibility granted to the victim who admits complicity as it opens up the possibility for a subtle kind of victim blaming. Judges need to suspect the expressions of compassion offered by victims of domestic violence in order to protect them, but they also must work harder in these cases, then perhaps in any others, to convince victims that their impact statements have been heard. 


\section{Saying "No"-Judicial Response in Sentencing Hearings}

Although we have used examples from the sentencing hearings we observed throughout our discussions of emotionology in the courtroom, we offer here some additional information on how judges say "no" to victims. As we found in our judicial conversations, the rhetorical strategies used to "turn down the victim" allude to the value of reason versus emotion, the need for objectivity and equality in the criminal justice system, the authority and responsibility of the judge, and the construction of the "normal" victim or the extremity of the case. The judges in the hearings we observed seemed to acknowledge or accept expressions of grief, offered explanations as to why expressions of compassion were or were not appropriate, and seemed unconvinced by expressions of anger. We observed nine sentences that fell within the guidelines, three downward departures, and six upward departures (some defendants faced multiple counts or one count might have been dismissed or folded into the other upon sentencing). Of the 17 hearings, eight were presided over by judges we interviewed.

Judges we observed often said "no" to an angry or grieving victim or victims' family when they requested a more severe sentence by appealing to reason; for example, the judges explained the objectivity of sentencing guidelines, cited other authorities, described the oversight possible during the probationary period, and referred to limited resources when explaining why they would not sentence the defendant to additional time or impose jail time rather than probation. In a case of identity theft, for example, the judge said "no" to the victim by first explaining how the sentencing grid worked and how the guidelines were meant to achieve consistency. He then described the shortage of prison beds and which offenses get priority for prison time (2/01/06). The judge in a case of criminal sexual conduct in the third degree also stated that even though he "doubted whether 48 months in prison would make the defendant a better person - he might come out even worse - the law and the guidelines were based on "just deserts"' (4/13/06). And, in a burglary case, the judge said that it would "cost the people of St. Paul approximately $\$ 50$ a day" to house the defendant in jail, "which further impacts the citizens" of the city $(4 / 1 / 06)$.

Other authorities also provided a source of "reasonable" response to a victim's appeal for a stronger sentence. In another case of criminal sexual conduct in the third degree, the judge referred to the scientific studies that sex offenders were less likely to re-offend if they received treatment rather than prison time, that he "still believed that sex offenders would be successfully treated," and that the probationary period including treatment would make this possible $(2 / 21 / 06)$. And, in a case of vehicular homicide, the defendant faced two counts; the judge departed upward on one to protect public safety but departed downward, saying "no" to one victim's family, because of the defendant's proven amenability to chemical dependency treatment, amenability attested to by probation (4/25/06). Finally, imposing probation rather than jail time seems to bolster a judge's authority. The probationary period gives the judge more flexibility in requiring oversight and treatment, particularly if the judge predicted that certain defendants were likely to fail to meet these requirements and then would serve their entire terms, again a way of appeasing victims who requested upward departures in duration. In a case of assault in the third degree and gross misdemeanor harassment/stalking, for example, the judge assured the victim and defendant that he was "well aware of the past history" of this 
domestic relationship and that probation was going to "keep a close watch" over the case. The judge emphasized that defendant would spend five years on probation, a longer period that usual, even though he would spend only 40 days in jail, and should he fail at probation, he would then serve 42 months in jail (3/31/06), an explanation that seemed almost a prediction.

As we explored earlier, judges also find themselves in the position of having to respond when a victim requests a lesser sentence, perhaps expressing compassion for the defendant. One victim of criminal sexual conduct in the third degree, a "stranger" rape, for example, said that she thought the defendant should be "locked up" but she did not argue for a specific sentence, expressing her hope that the defendant "had learned his lesson" (4/25/06); she was more interested in attesting that other victims could get over such crimes. The judge did not respond directly to her compassion when he sentenced within the guidelines but instead explained at length to the defendant the nature of the sentence and the implications for serving this sentence concurrent with a similar one in Illinois. On the other hand, in another case of criminal sexual conduct in the third degree, the victim's family had allowed the defendant to live with them when he violated the daughter. The victim's mother expressed that she had "taken control" of the event by giving an impact statement: "I don't hate him but hate the pain he caused us," she said $(2 / 23 / 06)$. The judge, however, asked how she could "find him [the defendant] amenable to probation when he wouldn't admit he did anything wrong," sentencing him within the guidelines for this crime. In this case, the judge rejected the victim's suggestions of a lesser sentence by stressing her special knowledge of the defendants' mindset.

As they mentioned in their conversations with us, judges also say "no" when they have assessed the extreme nature of the case, the details that take this case beyond "the norm." In a case of murder in the first degree, for example, the judge listened to the victim's step-father explain that he had once wanted "an eye for an eye" but now had a "cooler heart" after seeing that nothing would bring the victim back. The victim's mother also affirmed that no amount of suffering by the defendant would ever match that of the victim's family. The judge, however, departed upward because of the cruelty toward the victim who had been sleeping when she was stabbed, hit with a hammer, and choked to death $(5 / 15 / 06)$. And, in a case of unintentional homicide in the second degree, the judge departed upward from the guidelines because the defendant had refused to render the victim aid after he shot her (4/10/06). In these cases, as the judges expressed in our conversations with them, these crimes were not "average"; the judges emphasized the details of the case to distinguish them in their cruelty.

Again, although we cannot prove direct connections between judges' perceptions expressed in our conversations and their behavior on the bench, we do see some similarities between these perceptions and behaviors. As in their conversations, the judges do distinguish between emotion and reason when explaining their sentencing decisions, assert their authority to make these decisions, and describe the sentencing guidelines as objective and fair. They seem to respond, even though they might not agree, to expressions of compassion, accept grief as inevitable, and are resistant to anger. And, at least one judge, directly challenged the victim of domestic violence when she expressed compassion for the defendant. But as one judge explained to a victim: "Judges do not make these decisions lightly." But, "in this imperfect world," he hoped that the passage of time 
would help them heal (2/12/06). In many of the hearings then, the judges were challenged by how to justify sentencing decisions and still respond to impact statements.

\section{Conclusion}

We offer in this essay a look at how judges respond to victim impact statements, a genre that brings emotion directly into the courtroom, and, although in many cases the emotionology of the courtroom seems to match that reflected in general culture, we offer a further breakdown. We acknowledge that we cannot generalize greatly, given the number of judges and sites we studied, but we can say that the judges with whom we spoke frequently contrasted emotion and reason by discussing the potential conflicts between the legislated right to give an impact statement and the sentencing guidelines that govern felony cases. A theme pervasive in this contrasting was the need to maintain control and authority in the courtroom, a need that might perpetuate as well as result from this distinction between emotion and reason. In asserting that authority, judges often describe their options as limited, use the language of certainty, and avoid displays of emotion themselves. The victim who enters the courtroom to offer an impact statement then encounters a challenging and perhaps silencing setting.

Although the hierarchy of grief, anger, and compassion judges described again matched that described by many scholars of cultural emotionology, the judges with whom we spoke often offered specific justification for this hierarchy. Excessive expressions of grief threatened their authority in the courtroom, and so they might curtail them. Anger, on the other hand, was seldom seen as acceptable, no matter how healing it might be. So often linked to vengeance rather than retribution, anger, to the judges, seemed dishonest, immature, and useless in considering a plea negotiation or weighing sentencing options. Finally, in many cases, compassion was regarded as a mature and transcendent response to the personal effects of a crime, an indication that the victim had moved on. The compassionate victim was wise and cooperative, able to see beyond the personal effects of the crime to social needs for public safety and to understand the limited options available in sentencing. The compassionate victim in all cases but domestic violence caused little trouble for the court and was most likely to accept the conditions of a plea negotiation.

However, judicial reactions to impact statements and the emotional expressions they bring into the courtroom must be placed in context. This case of the domestic violence victim serves as an example and a special challenge for judges. Several judges we spoke with still viewed the domestic violence victim as "sick" or weak, unable to protect herself. This victim is denied agency when expressing compassion or asking for mercy for her abuser unless she has left or is at the point of leaving the relationship, is willing to admit complicity in the abuse, or can articulate specific conditions of probation, such as substance abuse treatment or anger management, that would help ensure her safety. Not all judges, of course, portrayed the domestic violence victim in this way, and at least one acknowledged that she was in a no-win situation, perceived as rational if she wants punishment, irrational if she wants leniency. The domestic violence victim, however, is still seen by some judges as quite different from other victims, particularly the victim of sexual assault. To many judges, the domestic violence victim is seen as an unfortunate 
obstacle to public safety, her own and those of future victims; moreover, most judges express genuine worry that she remains in danger and express a lack of confidence that legal proceedings can ever fully protect her. Unlike many other cases, judges must worry about the threat to this victim by this defendant.

Finally, judges all have unique personalities and different comfort levels; they bring their own experience and schemas to their work. In adding judicial response to impact statements to the scholarly mix on domestic violence and emotionology, however, we contribute some rich and real input that we were privileged to receive from our study participants and our access to the courtrooms of Minneapolis and St. Paul. We feel secure in proposing that judicial emotionology reflects cultural emotionology in labeling some emotions as good and some as bad, some as reasonable and some as excessive, and some as cooperative with the goals of retribution and some too closely tied to personal vengeance. Moreover, judicial emotionology grants or denies credibility or even agency to victims depending on how they align with that emotionology and the context of the case. With these issues in mind, we call for future studies that explore the truth tests victims face when giving impact statements. Although we contextualize our judicial conversations within our courtroom observations, we hope that future studies will continue to explore further not only what judges say about emotional expressions within impact statements but also what they do in deciding upon a sentence; ask how often are victims aware of how their expressions of grief, anger, and compassion are received according to the emotionology of the courtroom and how do they feel about this reception; and explore what further training on impact statements could help judges feel more comfortable, if this indeed is a goal, when hearing them in sentencing hearings. 